\title{
Ultraviolet (UV) B effects on growth and yield of three contrasting sweet potato cultivars
}

\author{
Z. CHEN ${ }^{*,+}$, W. GAO ${ }^{*, * *}$, K.R. REDDY***, M. CHEN", S. TADURI**,*, S.L. MEYERS ${ }^{\# \#,}$ \\ and M.W. SHANKLE ${ }^{\#}$
}

USDA UV-B Monitoring and Research Program, Natural Resource Ecology Laboratory, Colorado State University, Fort Collins, CO 80523, USA*

Department of Ecosystem Science and Sustainability, Colorado State University, Fort Collins, CO 80523, USA ${ }^{* *}$

Department of Plant and Soil Sciences, Box 9555, Mississippi State University, MS 39762, USA***

Department of Biotechnology, Kakatiya University, 506001 Warangal, Telangana State, India\#

Pontotoc Ridge-Flatwoods Branch Experiment Station, Mississippi State University, Pontotoc, MS 38863, USA

\begin{abstract}
Ground-level UV-B will stay at a high level in the next several decades and influence sweet potato growth and yield because of the remaining chlorofluorocarbons in the atmosphere. The study explored three UV-B (none, ambient, and elevated/projected) levels on three contrasting sweet potato cultivars (Beauregard, Hatteras, and Louisiana 1188) using sunlit plant growth chambers at Mississippi State University. The results showed that UV-B influenced three cultivars differently. Growth, photosynthetic rate, epidermal and leaf structure of Beauregard were negatively influenced under ambient and elevated UV-B. On the contrary, Hatteras was positively influenced, and Louisiana 1188 was influenced by elevated UV-B positively on leaf thickness and waxes content, but negatively on the vine length, dry mass, and leaf area. In summary, Beauregard, Louisiana 1188, and Hatteras were UV-B sensitive, moderately sensitive, and tolerant, respectively. Developing UV-B tolerant cultivars will benefit under both current and projected UV-B exposures.
\end{abstract}

Additional key words: combined response index; cultivar differences; gas exchange; Ipomoea batatas; leaf anatomy; water-use efficiency.

\section{Introduction}

The solar UV-B radiation at ground level is mainly influenced by ozone in the stratosphere because it is where most ozone resides in and absorbs approximately all the UV-C (200-280 nm), most of UV-B (280-315 nm), and a small amount of UV-A (320-400 nm) radiation. It was estimated that the peak value of UV-B might triple in the U.S. in the next fifty years without the Montreal Protocol (McKenzie et al. 2011). However, despite the success of Montreal Protocol, the global averaged ozone concentration will not return to the 1980's level until the mid-century because of the remaining chlorofluorocarbons (CFCs) in the atmosphere (Björn and McKenzie 2008,
McKenzie et al. 2011). Besides ozone, ground-level UV-B is also determined by solar angles, cloud cover, aerosols/ pollution, and surface albedo, which change with location and time (Hideg et al. 2013).

Plants are significantly influenced by UV-B radiation (Wargent and Jordan 2013). On the molecular level, UV-B radiation has damaging effects on the DNA, proteins, and membranes of plants because they are UV-sensitive targets (Jansen et al. 1998, Björn and McKenzie 2008, Prado et al. 2012). Approximately $20 \%$ of crops are sensitive to UV-B radiation regarding dry mass reduction (Teramura 1983). Previous studies had already covered soybean (Koti et al. 2007), cotton (Kakani et al. 2003), and maize (Singh et al. 2014, Wijewardana et al. 2016). For example, it was found

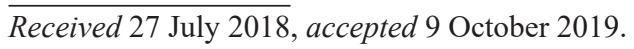

${ }^{+}$Corresponding author; e-mail: zigengchen1@gmail.com

Abbreviations: ADM - aboveground dry mass; BG - Beauregard; CA - calcium diacetate films; CFCs - chlorofluorocarbons; CRI combined response index; DAP - days after transplanting; FAA - formaldehyde; $\mathrm{F}_{\mathrm{v}}{ }^{\prime} / \mathrm{F}_{\mathrm{m}}{ }^{\prime}$ - photochemical efficiency of PSII in the light; $g_{\mathrm{s}}$ - stomatal conductance; HT - Hatteras; LA - leaf area; LA1188 - Louisiana 1188; LDM - leaf dry mass; $P_{\mathrm{N}}$ - net photosynthetic rate; PVC - polyvinyl chloride; SDM - stem dry mass; SEM - scanning electron microscope; SPAR - soil-plant-atmosphere research; SRDM - storage root dry mass; SRFM - storage root fresh mass; SRN - storage root number; TDM - total dry mass; $E$ - transpiration rate; USI - UV-B sensitivity index; UV - ultraviolet; VL - longest vine length; VNN - longest vine node number; WUE - water-use efficiency; $\Phi_{\mathrm{PSII}}-$ effective quantum yield of PSII photochemistry.

Acknowledgments: This research is supported by the US Department of Agriculture (USDA) UV-B Monitoring and Research Program, Colorado State University, and under USDA National Institute of Food and Agriculture Grant 2016-34263-25763 and NIFA-MIS 043040. We thank David Brand for his technical support and Chathurika Wijewardana, Firas Alsajri, Salah Jumaa, Naqeeb Hassas, and Ajaz Lone for their help during the experiment. We thank the Flatwoods Branch Experiment Station for providing sweet potato slips. This paper is from a thesis submitted to the Academic Faculty of Colorado State University in partial fulfillment of the requirements for the degree of Master of Science. 
that $10 \mathrm{~kJ} \mathrm{~m}^{-2} \mathrm{~d}^{-1} \mathrm{UV}-\mathrm{B}$ (the projected UV-B level) had multiple negative effects on maize (Zea mays L.) including reduced plant height (by 36\%), leaf area (by 22\%), and photosynthetic rate (by $5-15 \%$ ) compared to $0 \mathrm{~kJ} \mathrm{~m}^{-2} \mathrm{~d}^{-1}$ treatment (Singh et al. 2014). Similarly, soybean [Glycine $\max ($ L.) Merr.] showed reduction in plant height (by 7\%), leaf area (by $15 \%$ ), and photosynthetic rate (by $26 \%$ ) with the same UV-B treatments (Koti et al. 2007). Additionally, UV-B increased chemical composition of UV-absorbing compounds and pigments in maize leaves by $51 \%$ at $10 \mathrm{~kJ}$ $\mathrm{m}^{-2} \mathrm{~d}^{-1}$ UV-B $\left(24 / 16^{\circ} \mathrm{C}\right)$ (Singh et al. 2014).

Sweet potato [Ipomoea batatas (L.) Lam.] has strong adaptability to various environment conditions (Martin 1988). More than 400 varieties of sweet potato are grown globally (http://www.sweetpotatoes.com/About/ VarietiesandBotanicalInformation.aspx). In the U.S., sweet potato is mainly cultivated in high-temperature environments such as southern states and California (USDA 2002). Beauregard (BG), one of the most popular and well-studied sweet potato cultivars in Mississippi, released by Louisiana Agriculture Experiment Station in 1987, has a high-yield potential and strong resistance to soil rot and pox but weak resistance to root-knot nematode (Wehner et al. 2013). Hatteras (HT) was released by North Carolina State University near 2011 and commonly grown in North Carolina. Louisiana 1188 (LA1188) is an experimental genotype that was supposed to replace the BG. The objective of this study was to understand the sweet potato cultivar variability in the response to the effects of UV-B radiation.

The growth of sweet potato, especially the root initiation and development, in response to environmental factors induce significant alternation in yield and economic consequence (Godfray et al. 2010). Previous studies showed that, in general, soil moisture, soil and air temperature, nitrogen fertilizers are such environmental factors (Meyers 2014). More specifically, the early-season soil moisture, temperature, and nitrogen fertilizer determine root initiation; and the mid- and late-season ones determine biomass and yield (Villagarcia et al. 1998, Ukom et al. 2009, Gajanayake et al. 2013, 2015; Gajanayake and Reddy 2016).

However, the UV-B effects on various sweet potato cultivars have not been studied thoroughly. The daily ambient UV-B radiation observed by the USDA UV-B Monitoring and Research Program was in the range between $0.02-8.75 \mathrm{KJ} \mathrm{m}^{-2} \mathrm{~d}^{-1}$ (e.g., Singh et al. 2014) across the U.S. North Carolina, Mississippi, California, and Louisiana account for $78 \%$ of the U.S. sweet potato production, where the peak UV-B levels were in the range between $4-8 \mathrm{~kJ} \mathrm{~m}^{-2} \mathrm{~d}^{-1}$ in the growing season of 2015 (Fig. 1). Therefore, 5 and $10 \mathrm{KJ} \mathrm{m}^{-2} \mathrm{~d}^{-1}$ represent an almost near the ambient dose and potential higher dose in Mississippi in the future. This experiment with the computer-controlled environment was designed and conducted to understand the UV-B effects on three contrasting sweet potato cultivars. We hypothesize that ambient and projected UV-B radiation of 5 and $10 \mathrm{~kJ} \mathrm{~m}^{-2} \mathrm{~d}^{-1}$ have significant impacts on the sweet potato growth and yield; and sweet potato cultivars BG, HT, and LA1188

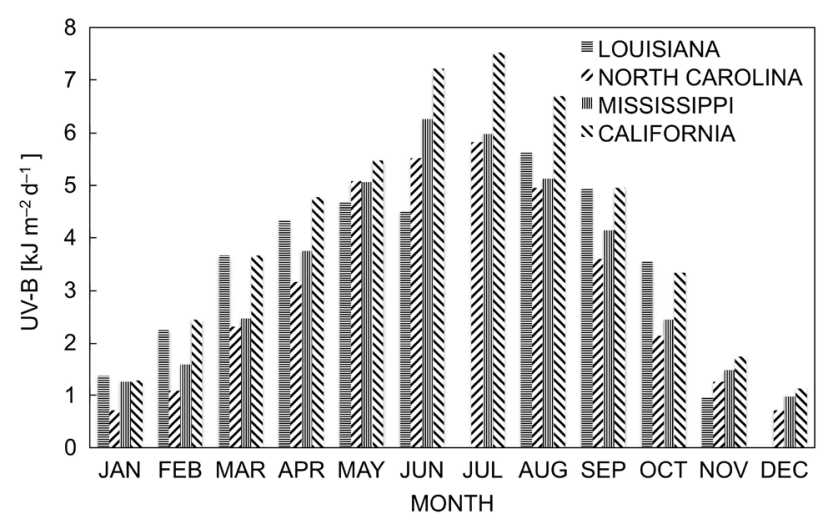

Fig. 1. Current (2015) UV-B levels (average daily sums Caldwell biological spectral weighting function $\left[\mathrm{kJ} \mathrm{m}^{-2} \mathrm{~d}^{-1}\right]$ ) in four U.S. States (Louisiana, North Carolina, Mississippi, and California) that contribute most $(>70 \%)$ sweet potato production. The data (July and December) in Louisiana are missing. Data source: UV-B Monitoring and Research Program.

vary in their responses to the ambient and projected UV-B radiation. The photosynthetic rate, the stomatal conductance, the longest vine length, the leaf area, the total dry mass, and other physiological parameters were measured, and a combined response index (CRI) was calculated from these parameters. Finally, the three types of sweet potato cultivars were classified based on their sensitivity to UV-B radiation.

\section{Materials and methods}

Experimental conditions and sweet potato cultivars: The study was conducted in three soil-plant-atmosphere research (SPAR) units located at the Rodney Foil Plant Science Research Center, Mississippi State, Mississippi, USA. Each SPAR unit was composed of a steel soil bin, a plexiglass chamber opaque solar UV-B radiation, heating and cooling system, and a monitoring and control system (Reddy et al. 2001). During the experiment, the weather conditions were set at $30 / 22^{\circ} \mathrm{C}, 400 \mu \mathrm{mol}\left(\mathrm{CO}_{2}\right) \mathrm{mol}^{-1}$, and $50 \%$ relative humidity that is optimum temperature for sweet potato. Field-grown BG, HT, and LA1188 step tip cuttings (slips), each containing four nodes, were transplanted into white polyvinyl chloride (PVC) pots (20 cm diameter by $30 \mathrm{~cm}$ high) on 15 July 2016. PVC pots were filled with a layer of $600 \mathrm{~g}$ of coarse gravel with a $3: 1(\mathrm{v} / \mathrm{v})$ mixture of sand and topsoil. Slips were transplanted with two nodes above the soil surface and two nodes below the soil surface. Nodes above the soil surface contained recently fully expanded leaves. Petioles on the lower two nodes were trimmed to $1 \mathrm{~cm}$ in length (Abukari et al. 2015). Water and nutrients were provided three times a day using a standard Hoagland's nutrient solution (Hewitt 1952). The amount of irrigation in each unit was based on the evapotranspiration measured on the previous day (Reddy et al. 2001). During the experiment, in order to simulate the natural shading effect caused by the surrounding edges of sweet potato canopy, black shade cloths were placed and adjusted twice weekly in 
each SPAR chamber. By using a pyranometer (Model 4-8, Eppley Laboratory Inc., Newport, RI, USA), throughout this experiment, the incoming daily solar radiation (285$2,800 \mathrm{~nm}$ ) outside of the sunlit growth chamber were measured, and the range was from 11.25 to $28.58 \mathrm{MJ} \mathrm{m}^{-2} \mathrm{~d}^{-1}$ with an average of $21.45 \mathrm{MJ} \mathrm{m}^{-2} \mathrm{~d}^{-1}$.

Treatments: A three by three factorial with three levels of UV-B $\left(0,5\right.$, and $\left.10 \mathrm{~kJ} \mathrm{~m}^{-2} \mathrm{~d}^{-1}\right)$ and three cultivars (BG, HT, and LA1188) were imposed at planting and continued until the final harvest $80 \mathrm{~d}$ after planting. Three UV-B treatments in each SPAR unit simulated the control group, ambient UV-B, and projected near-future UV-B, respectively (Singh et al. 2014). Within each SPAR unit, each cultivar was replicated six times. The 18 PVC pots in each unit were randomly arranged in two rows with $26.6 \mathrm{~cm}$ between rows and $25 \mathrm{~cm}$ between pots within each row. A square-wave supplementation system composed of eight fluorescent lamps ( $U V$-313 lamps, $Q$-Panel Company, Cleveland, OH, USA) $0.5 \mathrm{~m}$ above the canopy provided the proposed UV-B levels (under near ambient PAR) in each treatment from 8:00 to 16:00 h each day (Zhao et al. 2003). Calcium diacetate films (CA) were wrapped around each lamp to filter UV-C radiation and changed every 10 to $15 \mathrm{~d}$ to account for degradation of the CA properties to treatment UV-B levels. Daily UV-B radiation in the ambient and projected UV-B treatments was monitored at the top surface of sweet potato canopy using a UV digital radiometer and the intensity was adjusted using dimmable ballasts as needed. The UV-B energy delivered at the top of the plant canopy was checked daily with a UVX digital radiometer (UVP Inc., San Gabriel, California, USA) and calibrated against an Optronic Laboratory (Orlando, Florida, USA) Model 754 spectroradiometer, which was used to initially quantify lamp output. The rack height and lamp power were adjusted as needed at 08:00 $\mathrm{h}$ to maintain the respective UV-B radiation levels. The distance from lamps to the top of plants was always maintained at $0.5 \mathrm{~m}$ throughout the experiment. In the control units, unilluminated bulbs with frame were placed.

Photosynthesis and chlorophyll (Chl) fluorescence: At 34,48 , and $75 \mathrm{~d}$ after transplanting (DAP), photosynthetic rate $\left(P_{\mathrm{N}}\right)$ and fluorescence in light were measured on the fourth or fifth most recently fully expanded leaf of each plant between 10:00 and 14:00 h on sunny days using an LI-COR 6400 portable photosynthesis system integrated with a fluorescence chamber head (LI-COR 6400-40 leaf chamber fluorometer, $\mathrm{Li}$-COR Inc., Lincoln, NE, USA). While measuring photosynthesis $\left(P_{\mathrm{N}}\right)$, the instrument was set at PAR of $1,500 \mu \mathrm{mol}$ (photon) $\mathrm{m}^{-2} \mathrm{~s}^{-1}$ that is based on the average PAR measured inside the greenhouse, and temperature in the leaf cuvette to daytime temperature as $30^{\circ} \mathrm{C}, 400 \mu \mathrm{mol}\left(\mathrm{CO}_{2}\right) \mathrm{mol}^{-1}$, and $50 \%$ relative humidity. The flow rate through the chamber was adjusted to $350 \mathrm{~mol} \mathrm{~s}{ }^{-1} . P_{\mathrm{N}}$ and the fluorescence $\left(\mathrm{F}_{\mathrm{v}}{ }^{\prime} / \mathrm{F}_{\mathrm{m}}{ }^{\prime}\right)$ were recorded as the total coefficient of variation ( $\mathrm{CV}[\%])$ reached a value less than 0.5 . The instrument itself calculates stomatal conductance $\left(g_{\mathrm{s}}\right)$, transpiration $(E)$, and electron transport rate (ETR) by considering incoming and outgoing flow rates and leaf area. Intrinsic water-use efficiency (WUE) and the ratio of internal $\left(C_{\mathrm{i}}\right)$ to external $\left(C_{\mathrm{a}}\right) \mathrm{CO}_{2}$ concentration were estimated as the ratio of $P_{\mathrm{N}} / E$ and $C_{\mathrm{i}} / C_{\mathrm{a}} . \mathrm{F}_{\mathrm{v}}{ }^{\prime} / \mathrm{F}_{\mathrm{m}}{ }^{\prime}$ was calculated and determined as $\left(\mathrm{F}_{\mathrm{m}}{ }^{\prime}-\mathrm{F}_{\mathrm{s}}\right) / \mathrm{F}_{\mathrm{m}}{ }^{\prime}$ by the software in the instrument (Gajanayake et al. 2014, Wijewardana et al. 2016).

Leaf anatomical measurements: This methodology was described by Kakani et al. (2003). Three fully mature leaves were randomly selected from three individuals per cultivar per treatment, and segments of $2 \mathrm{~cm}$ by $0.5 \mathrm{~cm}$ were cut $5 \mathrm{~cm}$ from the base of the leaf blade and $2 \mathrm{~cm}$ from the main midrib. Leaf segments were stored in $2.5 \%$ glutaraldehyde in $0.1 \mathrm{M}$ phosphate buffer for scanning electron microscope (SEM) analysis for surface wax structures. Then, another three leaf segments, collected from the same leaves in the same way, were fixed in formaldehyde (FAA, acetic acid and alcohol at ratio by volume). After being infiltrated in Spurr's epoxy resin, sections of $10-\mu \mathrm{m}$ thickness were sectioned and stained, then digital micrographs were taken with a microscope equipped with a Canon EOS Rebel T3i/600D 18.0-megapixel camera (MartinMicroscope Co., Easley, SC, USA). Leaf thickness was measured on the image of sections in ratio.

Growth and developmental measurements: Longest vine length (VL), longest vine node number (VNN), leaf area (LA), storage root number (SRN), and storage root fresh mass (SRFM) were measured or counted on all plants at the final harvest, 80 DAP. LA was measured with the $L I-3100$ leaf area meter (Li-COR Inc., Lincoln, NE, USA) on all plants at the final harvest. Dry mass of plant components [leaf dry mass (LDM), stem dry mass (SDM) and storage root dry mass (SRDM)] were weighed after drying the material in a forced air oven that maintained at $80^{\circ} \mathrm{C}$ for $72 \mathrm{~h}$.

Statistical analysis: Two-way analysis of variance $(A N O V A)$ and LSD $(\alpha<0.05)$ were used to determine the differences between UV-B treatments and cultivars using $R$-Studio. A linear regression model was used to estimate the relationship between UV-B and CRI using EXCEL. Based on the index introduced by Dai et al. (1994a) and later modified by Koti et al. (2007), CRI was calculated from the individual response indices calculated based on each parameter using the following formula: $\mathrm{CRI}=$ $\left[\left(\mathrm{VL}_{\mathrm{t}}-\mathrm{VL}_{\mathrm{c}}\right) / \mathrm{VL}_{\mathrm{c}}+\left(\mathrm{LA}_{\mathrm{t}}-\mathrm{La}_{\mathrm{c}}\right) / \mathrm{La}_{\mathrm{c}}+\left(\mathrm{VNN}_{\mathrm{t}}-\mathrm{VNN}_{\mathrm{c}}\right) /\right.$ $\mathrm{VNN}_{\mathrm{c}}+\left(\mathrm{TDM}_{\mathrm{t}}-\mathrm{TDM}_{\mathrm{c}}\right) / \mathrm{TDM}_{\mathrm{c}}+\left(\mathrm{SRDM}_{\mathrm{t}}-\mathrm{SRDM}_{\mathrm{c}}\right) /$ $\left.\mathrm{SRDM}_{\mathrm{c}}\right] \times 100$, where $\mathrm{VL}$ is the longest vine length, LA is the leaf area of the plant, VNN is the node number of the longest vine, TDM is the total dry mass, and SRDM is the storage root dry mass under $\mathrm{t}$ (treatment) and c (control). The slope of the regression line of CRI against UV-B was calculated as a UV-B sensitivity index (USI). The negative slope, less negative slope, and positive slope were defined as sensitive, moderately sensitive, and tolerant to UV-B, respectively. The method had also been used to classify the UV-B sensitivity of rice (Dai et al. 1994a,b) and soybean (Koti et al. 2007), though some modification had been added on their equations. 


\section{Results}

Photosynthesis and $\mathrm{Chl}$ fluorescence: The daily ambient and projected UV-B level was monitored in the SPAR unit for $75 \mathrm{~d}$ (Fig. 2). At 75 DAP, significant effects of UV-B and cultivar were observed on the $P_{\mathrm{N}}$ on the fifth fully expanded leaves (Table 1). Averaged over cultivar difference, UV-B significantly decreased $P_{\mathrm{N}}$ under projected UV-B by $16.6 \%$ compared to the control group. Averaged over UV-B levels, the $P_{\mathrm{N}}$ of BG [29.4 $\mu \mathrm{mol}\left(\mathrm{CO}_{2}\right) \mathrm{m}^{-2} \mathrm{~s}^{-1}$ ] was significantly higher by $7.7 \%$ than that of LA1188 [27.1 $\mu \mathrm{mol}\left(\mathrm{CO}_{2}\right) \mathrm{m}^{-2} \mathrm{~s}^{-1}$. The maximum decline of $P_{\mathrm{N}}$ of BG and HT occurred at projected UV-B, and of LA1188 at

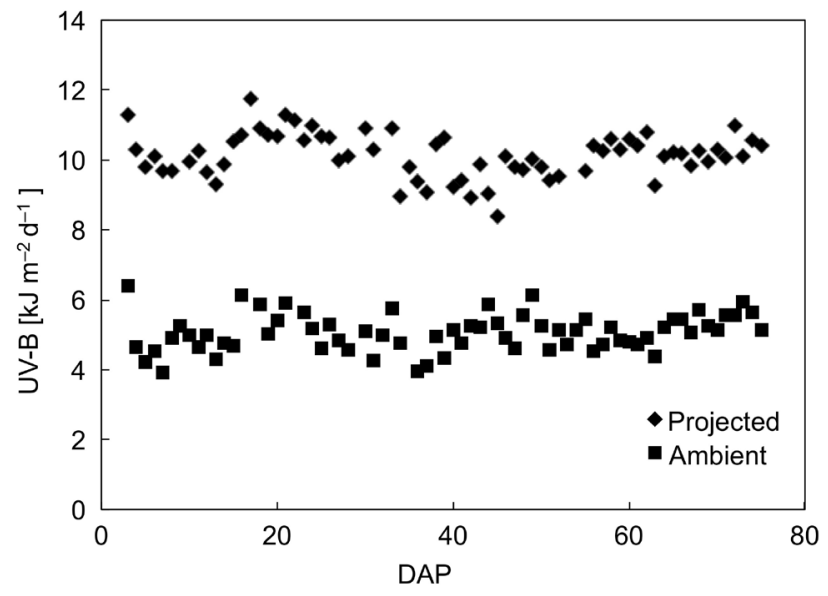

Fig. 2. Daily UV-B radiation level in the ambient and projected UV-B treatments monitored using a UV-X digital radiometer at noon. DAP - days after transplanting. ambient UV-B treatment by 44,10 , and $15 \%$, respectively (Table 1). Compared to the control group, UV-B decreased $g_{\mathrm{s}}$ with maximum decline for BG at ambient and projected UV-B by 37 and 78\%, respectively (Table 1). UV-B also significantly affected fluorescence parameters such as $\mathrm{F}_{\mathrm{v}}{ }^{\prime} / \mathrm{F}_{\mathrm{m}}{ }^{\prime}$ (Table 1).

Leaf structure: Significant effects of UV-B, cultivar, and UV-B $\times$ cultivar interaction were found on leaf thickness and the rest of internal component layers of leaf (palisade parenchyma, spongy parenchyma, upper and lower epidermis) (Table 2). UV-B significantly decreased total leaf thickness with maximum decline for BG at projected UV-B. However, UV-B also significantly increased total leaf thickness with maximum growth for HT and LA1188 under 5 and $10 \mathrm{~kJ} \mathrm{~m}^{-2} \mathrm{~d}^{-1}$, respectively. Total leaf thickness of sweet potato grown in control group was 2,693 $\mu \mathrm{m}$ (BG); $1,797 \mu \mathrm{m}(\mathrm{HT})$, and $1,485 \mu \mathrm{m}$ (LA1188). Compared to the control group, ambient and projected UV-B treatments decreased total leaf thickness by 25 and $32 \%$ for BG, and increased by 26 and $4 \%$ for HT, and increased $45 \%$ and $54 \%$ for LA 1188 , respectively (Table 2).

Epidermal ultrastructure observation: Images filmed by SEM on adaxial surface demonstrated that over the cultivar difference, epidermal wax content reached the maximum density at the ambient UV-B and minimum density at the projected UV-B (Fig. 3). It shows that all three cultivars had a significant change in leaf surface morphology. For all three cultivars, BG (Fig. $3 A, D, G$ ), HT (Fig. $3 B, E, H$ ), and LA1188 (Fig. $3 C, F, I$ ), the wax tube intensity increased at the ambient UV-B, and the epidermal cell suffered critical damage at the projected UV-B treatment.

Table 1. Effect of UV-B radiation on photosynthetic parameters in three sweet potato cultivars. $P_{\mathrm{N}}-$ net photosynthetic rate; $g_{s}$ - stomatal conductance; $E$ - transpiration rate; WUE - water-use efficiency; $\Phi_{\mathrm{PSII}}$ - effective quantum yield of PSII photochemistry; $\mathrm{F}_{\mathrm{v}}{ }^{\prime} / \mathrm{F}_{\mathrm{m}}{ }^{\prime}-$ maximal quantum yield of PSII photochemistry on the forth/fifth fully expanded leaf at $75 \mathrm{~d}$ after planting. Significance levels are indicated by $* * *, * * *$ and ns, representing $P<0.001, P<0.01, P<0.05$, and $P>0.05$, respectively. BG - Beauregard, HT - Hatteras, LA1188 - Louisiana 1188.

\begin{tabular}{|c|c|c|c|c|c|c|c|}
\hline Cultivar & UV-B $\left[\mathrm{kJ} \mathrm{m}^{-2} \mathrm{~d}^{-1}\right]$ & $\begin{array}{l}P_{\mathrm{N}}\left[\mu \mathrm{mol}\left(\mathrm{CO}_{2}\right)\right. \\
\left.\mathrm{m}^{-2} \mathrm{~s}^{-1}\right]\end{array}$ & $\begin{array}{l}g_{\mathrm{s}}\left[\mathrm{mol}\left(\mathrm{H}_{2} \mathrm{O}\right)\right. \\
\left.\mathrm{m}^{-2} \mathrm{~s}^{-1}\right]\end{array}$ & $\begin{array}{l}E\left[\operatorname{mmol}\left(\mathrm{H}_{2} \mathrm{O}\right)\right. \\
\left.\mathrm{m}^{-2} \mathrm{~s}^{-1}\right]\end{array}$ & $\begin{array}{l}\text { WUE }\left[\mu \mathrm{mol}\left(\mathrm{CO}_{2}\right)\right. \\
\left.\mathrm{mmol}^{-1}\left(\mathrm{H}_{2} \mathrm{O}\right)\right]\end{array}$ & $\Phi_{\mathrm{PSII}}$ & $\mathrm{F}_{\mathrm{v}}{ }^{\prime} / \mathrm{F}_{\mathrm{m}}^{\prime}$ \\
\hline \multirow[t]{4}{*}{ BG } & 0 & 35.17 & 0.65 & 9.85 & 3.93 & 0.26 & 0.56 \\
\hline & 5 & 33.45 & 0.41 & 10.47 & 3.34 & 0.31 & 0.59 \\
\hline & 10 & 19.55 & 0.14 & 7.59 & 2.55 & 0.12 & 0.48 \\
\hline & ANOVA & $* *$ & ns & $\mathrm{ns}$ & $\mathrm{ns}$ & ns & $*$ \\
\hline \multirow[t]{4}{*}{ HT } & 0 & 26.77 & 0.44 & 8.86 & 3.30 & 0.22 & 0.46 \\
\hline & 5 & 30.77 & 0.34 & 9.47 & 3.32 & 0.28 & 0.52 \\
\hline & 10 & 24.17 & 0.35 & 7.80 & 3.22 & 0.16 & 0.46 \\
\hline & ANOVA & ns & ns & ns & ns & ns & $\mathrm{ns}$ \\
\hline \multirow[t]{7}{*}{ LA1188 } & 0 & 27.40 & 0.42 & 8.71 & 3.17 & 0.27 & 0.49 \\
\hline & 5 & 23.20 & 0.26 & 8.10 & 2.92 & 0.18 & 0.45 \\
\hline & 10 & 30.80 & 0.51 & 9.55 & 3.20 & 0.22 & 0.48 \\
\hline & $A N O V A$ & ns & ns & ns & ns & ns & ns \\
\hline & UV-B & $* *$ & ns & ns & ns & ns & $*$ \\
\hline & Cultivar & $*$ & ns & ns & ns & ns & ns \\
\hline & UV-B $\times$ Cultivar & $* *$ & ns & ns & ns & ns & $\mathrm{ns}$ \\
\hline
\end{tabular}


Table 2. Effect of UV-B radiation on total leaf thickness and thickness of other component layers (palisade parenchyma, spongy parenchyma, upper and lower epidermis) in three sweet potato cultivars. Significance levels are indicated by $* * *, * *, *$ and $\mathrm{ns}$, representing $P<0.001, P<0.01, P<0.05$, and $P>0.05$, respectively. BG - Beauregard, HT - Hatteras, LA1188 - Louisiana 1188.

\begin{tabular}{|c|c|c|c|c|c|c|}
\hline Cultivar & $\begin{array}{l}\text { UV-B } \\
{\left[\mathrm{kJ} \mathrm{m}^{-2} \mathrm{~d}^{-1}\right]}\end{array}$ & $\begin{array}{l}\text { Palisade parenchyma } \\
{[\mu \mathrm{m}]}\end{array}$ & $\begin{array}{l}\text { Spongy parenchyma } \\
{[\mu \mathrm{m}]}\end{array}$ & $\begin{array}{l}\text { Upper epidermis } \\
{[\mu \mathrm{m}]}\end{array}$ & $\begin{array}{l}\text { Lower epidermis } \\
{[\mu \mathrm{m}]}\end{array}$ & $\begin{array}{l}\text { Total leaf thickness } \\
{[\mu \mathrm{m}]}\end{array}$ \\
\hline \multirow[t]{4}{*}{ BG } & 0 & 111.65 & 88.87 & 31.58 & 37.21 & 269.31 \\
\hline & 5 & 92.19 & 68.45 & 19.64 & 20.80 & 201.09 \\
\hline & 10 & 64.20 & 71.14 & 23.97 & 22.85 & 182.16 \\
\hline & ANOVA & $* * *$ & $* * *$ & $* * *$ & $* * *$ & $* * *$ \\
\hline \multirow[t]{4}{*}{ HT } & 0 & 82.63 & 54.04 & 20.96 & 22.04 & 179.67 \\
\hline & 5 & 98.01 & 87.64 & 19.63 & 20.89 & 226.17 \\
\hline & 10 & 81.39 & 66.57 & 19.76 & 19.93 & 187.67 \\
\hline & ANOVA & $* * *$ & $* * *$ & $* * *$ & $* * *$ & $* * *$ \\
\hline \multirow[t]{7}{*}{ LA1188 } & 0 & 60.87 & 48.76 & 18.28 & 20.61 & 148.52 \\
\hline & 5 & 83.64 & 89.26 & 20.59 & 21.13 & 214.61 \\
\hline & 10 & 106.21 & 88.67 & 10.36 & 22.93 & 228.17 \\
\hline & ANOVA & $* * *$ & $* * *$ & $* * *$ & $* * *$ & $* * *$ \\
\hline & UV-B & $* * *$ & $* * *$ & $* * *$ & $* * *$ & $* * *$ \\
\hline & Cultivar & $* * *$ & $* * *$ & $* * *$ & $* * *$ & $* * *$ \\
\hline & UV-B $\times$ Cultivar & $* * *$ & $* * *$ & $* * *$ & $* * *$ & $* * *$ \\
\hline
\end{tabular}

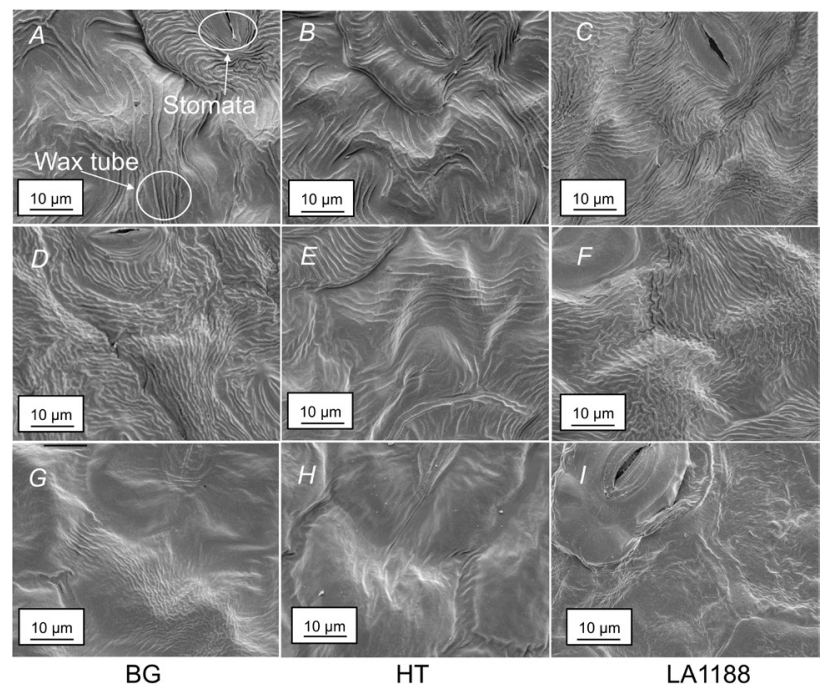

Fig. 3. Epicuticular wax morphology on leaf surfaces of the three sweet potato cultivars exposed to $0(A-C), 5(D-F)$, and $10 \mathrm{~kJ}$ $\mathrm{m}^{-2} \mathrm{~d}^{-1}(G-I)$ UV-B treatments. BG - Beauregard, HT - Hatteras, LA1188 - Louisiana 1188.

Growth and yield: UV-B radiation showed a significant effect on VL with significant cultivar differences (Table 3). UV-B significantly decreased VL with maximum decline for BG and LA1188 at the projected UV-B $\left(10 \mathrm{~kJ} \mathrm{~m}^{-2} \mathrm{~d}^{-1}\right)$. The VL of sweet potato grown under control group $\left(0 \mathrm{~kJ} \mathrm{~m}^{-2} \mathrm{~d}^{-1} \mathrm{UV}-\mathrm{B}\right)$ was $463.67 \mathrm{~cm}$ for $\mathrm{BG}$ and $320.33 \mathrm{~cm}$ for LA1188. Compared to the control group, the ambient (5) and projected $\left(10 \mathrm{~kJ} \mathrm{~m}^{-2} \mathrm{~d}^{-1}\right) \mathrm{UV}-\mathrm{B}$ treatments decreased VL by 15 and $39 \%$ for BG and 1.4 and $18 \%$ for LA 1188 , respectively (Table 3). Cultivar HT showed an opposite trend than that of the VL under the projected UV-B increases by $16 \%$ compared to control group.

Similarly, LA was also significantly affected by UV-B radiation and cultivar difference (Table 3 ). UV-B significantly decreased LA with a maximum decline for BG at the projected UV-B and LA1188 at ambient UV-B. LA of sweet potato cultivars grown in control group was $12,150 \mathrm{~cm}^{2}$ for BG; $6,009 \mathrm{~cm}^{2}$ for HT, and $5,003 \mathrm{~cm}^{2}$ for LA1188. Compared to the control group, the ambient and projected UV-B treatments decreased LA by 52 and $60 \%$ for $\mathrm{BG}$, and 42 and $24 \%$ for LA 1188 , respectively (Table 3). Again, HT showed an opposite trend than that of the LA under the ambient and projected UV-B increased 10 and $9 \%$ compared to the control group, respectively. LDM was also significantly affected by UV-B (Table 3 ). Averaged over cultivars, in control group was $36 \mathrm{~g}$, which decreased by 26 and $31 \%$ under the ambient and projected treatments, respectively.

UV-B significantly affected TDM (Table 3). Averaged over cultivars, the ambient and projected UV-B treatments significantly decreased TDM by 4 and $18 \%$, respectively (Table 3). Compared to control group, cultivars BG and HT showed the greatest reduction by 62 and $30 \%$ under the projected UV-B, respectively. Cultivar LA1188 showed the greatest reduction by $20 \%$ under the ambient UV-B.

Storage root number was significantly affected by UV-B (Table 3). Averaged over cultivars, the storage root number in control group was 7.4 , which was significantly reduced with the maximum decline of 45 and $29 \%$ under the ambient and projected treatments, respectively.

CRI and USI: The CRI, as an integration of the UV-B effect on sweet potato VL, LA, VNN, TDM, and SRDM, indicated the sensitivity of sweet potato cultivars to elevated UV-B radiation. The result showed that cultivar HT had a positive USI (6.14), and cultivar BG had a greater negative 
Table 3. Effect of UV-B radiation on the longest vine length (VL), vine node number (VNN), leaf area (LA), total dry mass (TDM), aboveground dry mass (ADM), storage root dry mass (SRDM), and storage root number (SRN) in three sweet potato cultivars. Significance levels are indicated by ***,*** and ns, representing $P<0.001, P<0.01, P<0.05$, and $P>0.05$, respectively. BG - Beauregard, HT - Hatteras, LA1188 - Louisiana 1188.

\begin{tabular}{|c|c|c|c|c|c|c|c|c|}
\hline Cultivar & $\begin{array}{l}\text { UV-B } \\
{\left[\mathrm{kJ} \mathrm{m}^{-2} \mathrm{~d}^{-1}\right]}\end{array}$ & $\begin{array}{l}\mathrm{VL} \\
{[\mathrm{cm}]}\end{array}$ & $\begin{array}{l}\text { VNN } \\
\text { [per plant] }\end{array}$ & $\begin{array}{l}\text { LA } \\
{\left[\mathrm{cm}^{2} \text { per plant }\right]}\end{array}$ & $\begin{array}{l}\text { TDM } \\
{\left[\mathrm{cm}^{2} \text { per plant }\right]}\end{array}$ & $\begin{array}{l}\mathrm{ADM} \\
{\left[\mathrm{cm}^{2} \text { per plant }\right]}\end{array}$ & $\begin{array}{l}\text { SRDM } \\
{\left[\mathrm{cm}^{2} \text { per plant }\right]}\end{array}$ & $\begin{array}{l}\text { SRN } \\
\text { [per plant] }\end{array}$ \\
\hline \multirow[t]{4}{*}{ BG } & 0 & 463.67 & 54.00 & $12,150.08$ & 235.94 & 149.39 & 78.84 & 7.33 \\
\hline & 5 & 393.50 & 48.00 & $4,868.76$ & 218.66 & 144.24 & 66.68 & 3.33 \\
\hline & 10 & 282.33 & 44.33 & $5,841.06$ & 88.61 & 60.60 & 76.19 & 3.17 \\
\hline & ANOVA & ns & ns & $*$ & $*$ & $*$ & ns & $*$ \\
\hline \multirow[t]{4}{*}{ HT } & 0 & 290.50 & 57.00 & $6,008.77$ & 122.19 & 83.02 & 36.70 & 6.33 \\
\hline & 5 & 339.33 & 52.83 & $6,610.83$ & 152.10 & 99.32 & 49.23 & 5.17 \\
\hline & 10 & 338.17 & 60.67 & $6,544.70$ & 158.37 & 104.02 & 59.93 & 6.33 \\
\hline & ANOVA & ns & ns & $*$ & ns & ns & ns & ns \\
\hline \multirow[t]{7}{*}{ LA1188 } & 0 & 320.33 & 57.50 & $5,002.55$ & 165.99 & 97.42 & 73.72 & 8.67 \\
\hline & 5 & 315.83 & 59.67 & $2,884.51$ & 134.81 & 97.97 & 34.88 & 3.83 \\
\hline & 10 & 260.50 & 53.00 & $3,816.49$ & 182.28 & 123.21 & 51.12 & 6.33 \\
\hline & ANOVA & $\mathrm{ns}$ & $\mathrm{ns}$ & $*$ & ns & ns & ns & $*$ \\
\hline & UV-B & $*$ & ns & $* * *$ & $* *$ & $*$ & $\mathrm{~ns}$ & $*$ \\
\hline & Cultivar & $*$ & ns & $* * *$ & ns & ns & ns & ns \\
\hline & UV-B $\times$ Cultivar & ns & ns & $* * *$ & $*$ & ns & $\mathrm{ns}$ & $\mathrm{ns}$ \\
\hline
\end{tabular}

USI (-17.14) than cultivar LA1188 (-4.04) (Fig. 4). So the CRI classified the sweet potato cultivars BG, LA1188, and HT into sensitive, moderately sensitive, and tolerant of the ambient and projected UV-B.

\section{Discussion}

Our results suggest that ambient and projected UV-B affect differently three sweet potato cultivars. For cultivars BG and LA1188, VL, LA and TDM decreased with increasing UV-B. Similar reductions in plant height, leaf area, and total dry mass caused by UV-B have been reported on cotton (Gao et al. 2003, Zhao et al. 2003), maize (Tevini et al. 1991, Mark and Tevini 1997, Wijewardana et al. 2016), rice (Coronel et al. 1990, Barnes et al. 1993, Dai et al. 1994a,b), soybean (Reed et al. 1992, Koti et al. 2007), and pea (Gonzalez et al. 1996). The reduction in VL and LA may be caused by the alternation in biosynthesis of some hormones and decrease in cell wall loosening due to the UV-B (Saile-Mark and Tevini 1997). The concomitant reduction in TDM and $P_{\mathrm{N}}$ suggest that the dry mass loss may be due to the limitation in net photosynthesis carbon gain. The experiment showed the ambient UV-B significantly reduced the storage root number the most, and the projected UV-B somehow stimulated the development of the storage root during the early age. However, cultivar HT, which was released in recent years, has some completely different characteristics and responses to UV-B that we have not studied thoroughly. For example, the VL, LA, and TDM of cultivar HT increased with increasing UV-B. A similar response was found on brood bean and wheat that the dry mass of the plant increased with the rising UV-B (Al-Oudat et al. 1998). This suggests that the UV-B effect is species/cultivar specific and sometimes it benefits the growth and development of plants (Hideg et al. 2013). The photosynthetic rate of BG was negatively correlated with UV-B, but HT and LA1188 had the maximum values under the ambient and projected UV-B respectively, demonstrating their UV-resistance potentials. Prior study has shown that the UV-B reduced photosynthesis by damaging photosynthetic organs, such as photosystems and chloroplasts membrane, and by decreasing stomatal

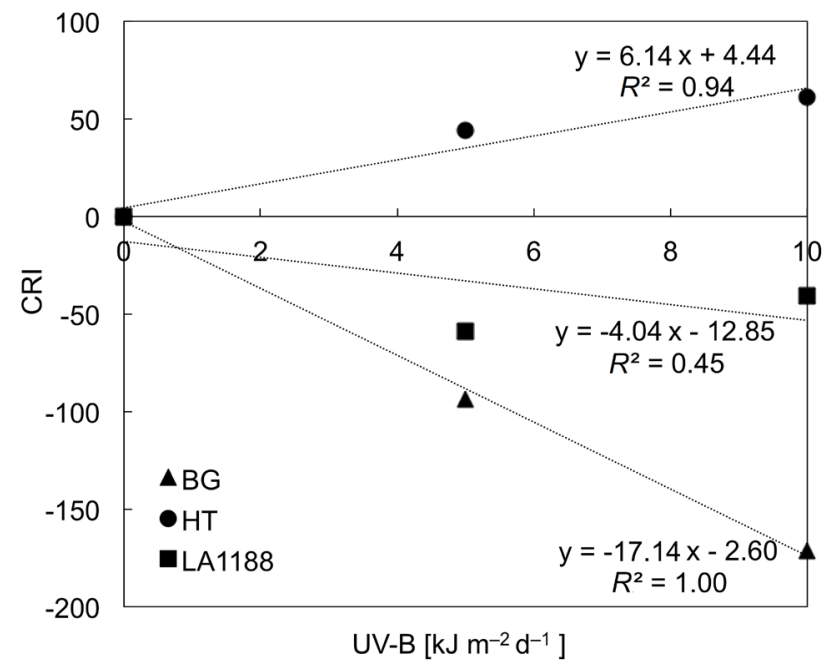

Fig. 4. Combined response index (CRI), which sums the relative responses in the longest vine length (VL), vine node number (VNN), leaf area (LA), total dry mass (TDM), and storage root dry mass (SRDM), due to UV-B radiation regressed over respective levels $\left(0,5,10 \mathrm{~kJ} \mathrm{~m}^{-2} \mathrm{~d}^{-1}\right)$ of UV-B radiation on the three sweetpotato cultivars (BG - Beauregard, HT - Hatteras, and LA1188 - Louisiana 1188). 
activity (Nogués et al. 1999), which resulted in the loss of sweet potato biomass.

On visual observation, the wax tubes were more abundant and denser under both the ambient UV-B and almost disappeared under the projected UV-B (Fig. 3). Other studies have found similar results of increased wax tubes on pea and cotton leaves (Corlett et al. 1997, Kakani et al. 2003). The similar result is also supported by Fig. 3, which shows epicuticular wax morphology on leaf surfaces of sweet potato exposed to the control group (Fig. 3A-C), the ambient UV-B (Fig. $3 D-F$ ), and the projected UV-B (Fig. 3G-I). The visual observation showed that all the sweet potato leaf wax tube density increased when exposed to the ambient UV-B and decreased when exposed to the projected UV-B. The elevated UV-B stimulated leaf to produce more wax content and the negative effect observed under the projected UV-B may be due to the critical UV-B damage on the epidermal cell. Since the wax tube density significantly decreased between 5 and $10 \mathrm{~kJ} \mathrm{~m}^{-2} \mathrm{~d}^{-1}$ (Fig. 3), UV-B sensitivity threshold for sweet potato leaves should be between these two UV-B exposure levels, similar to the UV-B effects on wax content observed in maize (Singh et al. 2014). The epidermal ultrastructure also differed in the cultivars. Under the ambient UV-B, the cultivar HT (Fig. $3 B, E, H$ ) showed fewer wax tubes than that of $\mathrm{BG}$ (Fig. $3 A, D, G$ ) and LA1188 (Fig. $3 C, F, I$ ), indicating that HT might adapt well to the ambient UV-B environment than the other two cultivars. Under the projected UV-B, the cultivar LA1188 showed the complete guard cells while the other two experienced serious damages, indicating that LA1188 has a better chance to survive under an elevated UV-B environment.

Based on the measurements, UV-B had a significantly negative and positive effect on the growth and yield of cultivar BG and HT, respectively, which fit the CRI results that $\mathrm{BG}$ and $\mathrm{HT}$ were UV-B sensitive and UV-B tolerant, respectively. On the other hand, cultivar LA1188 was moderately sensitive to UV-B, but it showed a better adaption to elevated UV-B than ambient UV-B environment by visual observation on the leaf structure.

Conclusions: In the experiment, the responses of three contrasting sweet potato cultivars, BG, HT, and LA1188, to three levels of UV-B $\left(0,5\right.$, and $\left.10 \mathrm{~kJ} \mathrm{~m}^{-2} \mathrm{~d}^{-1}\right)$ radiation were evaluated in sunlit plant growth chambers. Plants were grown under these UV-B treatments for $80 \mathrm{~d}$. Growth and developmental parameters were measured at the end of the experiment. Sweet potato cultivar variability made a difference in the response to UV-B. The ambient $\left(5 \mathrm{~kJ} \mathrm{~m}^{-2} \mathrm{~d}^{-1}\right)$ and projected UV-B $\left(10 \mathrm{~kJ} \mathrm{~m}^{-2} \mathrm{~d}^{-1}\right)$ of UV-B radiation inhibited most of the measured growth and physiological parameters of BG, but somehow assisited to the growth of HT. Based on CRI and USI, BG, the most commonly grown cultivar in Mississippi, was sensitive to elevated UV-B radiation, and LA1188 and HT were classified moderately sensitive and tolerant to UV-B radiation, respectively.

In summary, the current and projected UV-B will have implications for sweet potato growth and yield. Significant variability among the cultivars indicates developing UV-B tolerant cultivars will be more productive under current and future UV-B environments. Large-scale genomes to phenomes studies are needed to identify the lines and the genes that are associated with UV-B tolerance and incorporating those traits into region-specific more productive cultivars will benefit the sweet potato industry.

\section{References}

Abukari I.A., Shankle M.W., Reddy K.R.: Sweetpotato [Ipomoea batatas (L.) Lam.] response to S-metolachlor and rainfall under three temperature regimes. - Am. J. Plant Sci. 6: 702717, 2015.

Al-Oudat M., Baydoun S.A., Mohammad A.: Effects of enhanced UV-B on growth and yield of two Syrian crops wheat (Triticum durum var. Horani) and broad beans (Vicia faba) under field conditions. - Environ. Exp. Bot. 40: 11-16, 1998.

Barnes P.W., Maggard S., Holman S.R., Vergara B.S.: Intraspecific variation in sensitivity to UV-B radiation in rice. - Crop Sci. 33: 1041-1046, 1993.

Björn L.O., McKenzie R.L.: Ozone depletion and the effects of ultraviolet radiation. - In: Björn L.O. (ed.): Photobiology. Pp. 503-530. Springer, New York 2008.

Corlett J.E., Stephen J., Jones H.G. et al.: Assessing the impact of UV-B radiation on the growth and yield of field crops. In: Lumsden P.J. (ed.): Plants and UV-B. Responses to Environmental Change. Pp. 195-212. Cambridge University Press, Cambridge 1997.

Coronel V.P., Dai Q.J., Vergara B.S., Teramura A.: Preliminary study on response of rice seedlings to enhanced UV-B radiation. - Int. Rice Res. Newslett. 15: 37-37, 1990.

Dai Q.J., Peng S.B., Chavez A.Q., Vergara B.S.: Intraspecific responses of 188 rice cultivars to enhanced UVB radiation. Environ. Exp. Bot. 34: 433-442, 1994a.

Dai Q.J., Vergara B.S., Chavez A.Q., Peng S.B.: Response of rice plants from different regions to Ultraviolet-B radiation. - Int. Rice Res. Notes 19: 15-16, 1994b.

Gajanayake B., Reddy K.R., Shankle M.W., Arancibia R.A.: Early-season soil moisture deficit reduces sweetpotato storage root initiation and development. - HortScience 48: 1457 1462, 2013.

Gajanayake B., Reddy K.R., Shankle M.W., Arancibia R.A.: Growth, developmental, and physiological responses of two sweetpotato (Ipomoea batatas L. [Lam]) cultivars to early season soil moisture deficit. - Sci. Hortic.-Amsterdam 168: 218-228, 2014.

Gajanayake B., Reddy K.R., Shankle M.W.: Quantifying growth and developmental responses of sweetpotato to mid-and lateseason temperature. - Agron J. 107: 1854-1862, 2015.

Gajanayake B., Reddy K.R.: Sweetpotato responses to mid-and late-season soil moisture deficits. - Crop Sci. 56: 1865-1877, 2016.

Gao W., Zheng Y.F., Slusser J.R., Heisler G.M.: Impact of enhanced ultraviolet-B irradiance on cotton growth, development, yield, and qualities under field conditions. Agr. Forest Meteorol. 120: 241-248, 2003.

Godfray H.C.J., Beddington J.R., Crute I.R. et al.: Food security: The challenge of feeding 9 billion people. - Science 327: 812-818, 2010.

Gonzalez R., Paul N.D., Percy K. et al.: Responses to ultraviolet-B radiation ( $280-315 \mathrm{~nm}$ ) of pea (Pisum sativum) lines differing in leaf surface wax. - Physiol. Plantarum 98: 852-860, 1996.

Hewitt E.J.: Sand and Water Culture Methods Used in the Study of Plant Nutrition. Pp. 202-232. Farmham Royal Commonwealth Agriculture Bureaux, Bucks 1952. 
Hideg É., Jansen M.A., Strid Å.: UV-B exposure, ROS, and stress: inseparable companions or loosely linked associates. Trends Plant Sci. 18: 107-115, 2013.

Jansen M.A., Gaba V., Greenberg B.M.: Higher plants and UV-B radiation: balancing damage, repair and acclimation. - Trends Plant Sci. 3: 131-135, 1998.

Kakani V.G., Reddy K.R., Zhao D., Mohammed A.R.: Effects of ultraviolet-B radiation on cotton (Gossypium hirsutum L.) morphology and anatomy. - Ann. Bot.-London 91: 817-826, 2003.

Koti S., Reddy K.R., Kakani V.G. et al.: Effects of carbon dioxide, temperature and ultraviolet-B radiation and their interactions on soybean (Glycine max L.) growth and development. Environ. Exp. Bot. 60: 1-10, 2007.

Mark U., Tevini M.: Effects of solar ultraviolet-B radiation, temperature and $\mathrm{CO}_{2}$ on growth and physiology of sunflower and maize seedlings. - Plant Ecol. 128: 225-234, 1997.

Martin F.W.: Genetic and physiological basis for breeding and improving the sweetpotato. - In: Degras L. (ed.): Proceedings of the VII ${ }^{\text {th }}$ Symposium of the International Society for Tropical Root Crops, Guadeloupe, 1-6 July 1985. Pp. 749762. INRA, Paris 1988

McKenzie R.L., Aucamp P.J., Bais A.F. et al.: Ozone depletion and climate change: impacts on UV radiation. - Photoch. Photobio. Sci. 10: 182-198, 2011.

Meyers S.L., Arancibia R.A., Shankle M.W. et al.: Sweetpotato storage root initiation. Pp. 3. Mississippi State University Extension Service, Starkville 2014.

Nogués S., Allen D.J., Morison J.I., Baker N.R.: Characterization of stomatal closure caused by ultraviolet-B radiation. - Plant Physiol. 121: 489-496, 1999.

Prado F.E., Rosa M., Prado C. et al.: UV-B radiation, its effects and defense mechanisms in terrestrial plants. - In: Ahmad P., Prasad M.N.V. (ed.): Environmental Adaptations and Stress Tolerance of Plants in the Era of Climate Change. Pp. 57-83. Springer, New York 2012.

Reddy K.R., Hodges H.F., Read J.J. et al.: Soil-Plant-AtmosphereResearch (SPAR) facility - a tool for plant research and modeling. - Biotronics 30: 27-50, 2001.

Reed H.E., Teramura A.H., Kenworthy W.J.: Ancestral US soybean cultivars characterized for tolerance to ultraviolet-B radiation. - Crop Sci. 32: 1214-1219, 1992.

Saile-Mark M., Tevini M.: Effects of solar UV-B radiation on growth, flowering and yield of central and southern European bush bean cultivars (Phaseolus vulgaris L.). - Plant Ecol. 128: 115-125, 1997.

Singh S.K., Reddy K.R., Reddy V.R., Gao W.: Maize growth and developmental responses to temperature and ultraviolet-B radiation interaction. - Photosynthetica 52: 262-271, 2014.

Teramura A.H.: Effects of ultraviolet-B radiation on the growth and yield of crop plants. - Physiol. Plantarum 58: 415-427, 1983.

Tevini M., Mark U., Fieser G., Saile M.: Effects of enhanced solar UV-B radiation on growth and function of selected crop plant seedlings. - In: Riklis E. (ed.): Photobiology. Pp. 635649. Springer, Boston 1991.

Ukom A.N., Ojimelukwe P.C., Okpara D.A.: Nutrient composition of selected sweet potato [Ipomea batatas (L.) Lam.] varieties as influenced by different levels of nitrogen fertilizer application. - Pak. J. Nutr. 8: 1791-1795, 2009.

Villagarcia M.R., Collins W.W., Raper C.D.: Nitrate uptake and nitrogen use efficiency of two sweetpotato genotypes during early stages of storage root formation. - J. Am. Soc. Hortic. Sci. 123: 814-820, 1998.

Wargent J.J., Jordan B.R.: From ozone depletion to agriculture: understanding the role of UV radiation in sustainable crop production. - New Phytol. 197: 1058-1076, 2013.

Wehner T.C., Mou B., McCreight J.D. et al.: Vegetable cultivar descriptions for North America. List 27, 2013. HortScience 48: 245-286, 2013.

Wijewardana C., Henry W.B., Gao W., Reddy K.R.: Interactive effects on $\mathrm{CO}_{2}$, drought, and ultraviolet-B radiation on maize growth and development. - J. Photoch. Photobio. B 160: 198-209, 2016.

Zhao D., Reddy K.R., Kakani V.G., Read J.J.: Growth and physiological responses of cotton (Gossypium hirsutum L.) to elevated carbon dioxide and ultraviolet-B radiation under controlled environment conditions. - Plant Cell Environ. 26: 771-782, 2003.

(C) The authors. This is an open access article distributed under the terms of the Creative Commons BY-NC-ND Licence. 